\title{
UPAYA GURU DALAM MENGEMBANGKAN KARAKTER ANAK USIA DINI MELALUI KETELADANAN DAN PEMBIASAAN DI PAUD AL-AMIEN GUNUNG ELEH KEDUNGDUNG SAMPANG
}

\author{
Umrotul Hasanah \\ Institut Agama Islam Negeri Madura \\ Email: umrotulhasanah966@gmailm.com
}

\begin{abstract}
The purpose of this study was to determine how teachers' efforts in building the character of early childhood in Al-Amien PAUD Gunung Eleh Kedungdung Sampang. The target of this research is the formation of early childhood character through exemplary and habituation. This type of research is a descriptive study with qualitative research methods. This research information collection technique with the method of observation and interviews. Data analysis in this study used descriptive analysis. The results showed that building the character of children in school must be with habituation, exemplary teachers and all parties of the school and parents at home. Habits and examples are applied as follows: 1) teach honest actions, 2) teach children about the attitude of responsibility, 3) teach children about disciplinary actions, 4) cooperate with friends.
\end{abstract}

Keywords: Developing Character, Early Childhood, Exemplary, Habituation,

\begin{abstract}
Abstrak
Tujuan penelitian ini adalah untuk mengetahui bagaimana upaya guru dalam membangun karakter anak usia dini di PAUD Al-Amien Gunung Eleh Kedungdung Sampang. Target penelitian ini adalah terbentuknya karakter anak usia dini melalui keteladanan dan pembiasaan. Jenis penelitian ini adalah penelitian deskriptif dengan metode penelitian kualitatif. Teknik pengumpulan informasi penelitian ini dengan metode observasi dan wawancara. Analisis data penelitian ini menggunakan analisis deskriptif. Hasil penelitian menunjukan bahwa membangun karakter anak disekolah harus dengan pembiasaan, keteladanan guru dan semua pihak sekolah maupun orang tua di rumah. Pembiasaan dan keteladanan yang diterapkan sebagai berikut: 1) mengajarkan perbuatan jujur, 2) mengajarkan anak tentang sikap tanggung jawab, 3) mengajarkan anak tentang perbuatan disiplin, 4) bekerja sama dengan temannya.
\end{abstract}

Kata kunci: Mengembangkan Karakter, Anak Usia Dini, Keteladanan, Pembiasaan 


\section{PENDAHULUAN}

Membangun karakter bagi generasi bangsa dewasa ini memang sangat penting. Hal ini dapat dilihat dari fenomena-fenomena yang terjadi saat ini dan tantangan masa depan yang dihadapi semakin kompleks. Karakter-karakter umum seperti jujur, disiplin, taat aturan, atau bertanggung jawab sudah semakin hilang. Sebagai bukti fenomena yang terjadi adalah maraknya upaya-upaya mencontek ataupun plagiasi di lingkungan pendidikan menunjukkan kurangnya kesadaran untuk berprilaku jujur. Belum lagi peningkatan kasuskasus korupsi yang sering diberitakan oleh media massa yang menggambarkan semakin pudarnya sikap jujur. Kedisiplinan dan tanggung jawab generasi bangsa kadangkala hanya muncul ketika diawasi dan diancam dengan hukuman bukan melekat sebagai bagian dari karakter mereka (Nisa, 2016).

Menurut Syarifuddin saat ini pendidikan karakter menjadi salah satu isu pendidikan nasional dengan sasaran peserta didik. Sejauh ini sedang mengemuka upaya mencari format pendidikan karakter yang diperlukan dalam membangun karakter bangsa. Oleh sebab itu, banyak harapan supaya pendidikan karakter menjadi bagian penting dalam keseluruhan program pendidikan nasional dewasa ini. Dengan formulasi pendidikan karakter yang jelas konsep dasar dan program pelaksanaannya maka diharapkan pembentukan karakter bangsa sesuai yang diharapkan akan menjadi kenyataan (Syarifuddin, 2016).

Pendidikan karakter bertujuan untuk mengembangkan kemampuan peserta didik agar peserta didik mampu mengenal, peduli dan menginternalisasi nilai-nilai sehingga mampu berperilaku sebagai insan kamil (Shalihah, 2013). Sejalan dengan tujuan pendidikan nasional Indonesia, pendidikan Islam pun memiliki tujuan untuk mengembangkan potensi manusia dimana karakter merupakan salah satu aspek yang harus dikembangkan melalui pendidikan. Lebi dari itu, karakter atau dalam perspektif agama Islam lebih sering disebut dengan akhlak ini tidak dapat lepas dari aspek lain, misalnya aspek akidah (Shalihah, 2013).

Membangun karakter bersifat memperbaiki, membina, mendirikan, mengadakan sesuatu. Sedangkan "Karakter" adalah tabiat, watak, sifat-sifat kejiwaan, akhlak atau budi pekerti yang membedakan seseorang dari yang lain. Dalam konteks disini adalah suatu proses atau usaha yang dilakukan untuk membina, memperbaiki dan atau membentuk tabiat, watak, sifat kejiwaan, akhlak mulia, insan manusia sehingga menunjukan perangai dan tingkah laku yang baik berlandaskan nilai-nilai Pancasila (Saleh, 2012). Membangun karakter anak usia dini tidak hanya disekolah, orang tua juga harus terlibat dalam membentuk dan menanamkan karakter yang baik pada anak.

Pembentukan karakter ibarat mengukir. Sifat ukiran adalah melekat kuat di atas benda yang diukir, tidak mudah usang tertelan waktu atau halus karena gesekan. Menghilangkan ukiran sama saja dengan menghilangkan benda yang di ukir itu, karena ukiran melekat dan menyatu dengan bendanya. Demikian juga dengan karakter yang merupakan sebuah pola, baik itu pikiran, perasaan, sikap, maupun tindakan, yang melekat pada diri seseorang dengan sangat kuat dan sulit dihilangkan. Proses pembentukan karakter pada anak juga ibarat mengukir atau memahat jiwa sedemikian rupa, sehingga akan unik, menarik, dan berbeda antara satu dan lainnya.

Membentuk karakter memang tidak semudah membalik telapak tangan, jika karakter ibarat sebuah bangunan yang kokoh, butuh waktu yang lama dan energi yang tidak sedikit untuk mengubahnya. berbeda dengan bangunan yang tidak permanen yang menggunakan bahan-bahan rapuh, maka mengubahnyapun akan lebih cepat dan mudah. Tetapi karakter bukanlah sesuatu yang mudah diubah, maka tidak ada pilihan lain bagi kita semua kecuali membentuk karakter anak mulai sejak dini. 
Berdasarkan pra penelitian yang dilakukan oleh penulis di PAUD Al-Amien Gungung Eleh Kedungdung Sampang, sudah terlihat kebiasaan anak yang berbicara jujur saat melakukan kesalahan, terlihat asyik bermain dengan temannya, tidak terlambat datang kesekolah, dan terlihat anak membuang sampah pada tempatnya. Dengan demikian pembentukan karakter di PAUD Al-Amien, sudah dilaksanakan melalui setiap materi pembelajaran maupun setiap kegiatan yang melibatkan anak secara langsung. Pembelajaran yang dilakukan tidak hanya menuntut mereka memiliki kompetensi kognitif saja akan tetapi juga memiliki kompetensi afektif dan disertai dengan memberikan pembiasaan, keteladanan, dan pendisiplinan agar nilai-niai yang diterapkan pada anak usia dini tersebut tertanam dalam dirinya sehingga akan menjadi pengalaman dan pembudayaan dalam kehidupan sehari-hari, Semua itu tidak akan berhasil jika menggunakan strategi yang tidak sesuai.

Berkaitan dengan hal tersebut PAUD Al-Amien Gungung Eleh Kedungdung Sampang, menggunakan berbagai macam metode dalam pembentukan karakter anak usia dini di antaranya pembiasaan, keteladanan, pendisiplinan yang merupakan kegiatan dalam pembelajaran. Terbentuknya karakter memerlukan proses yang relatif lama dan terus menerus. Pembentukan karakter tidak cukup hanya diajarkan melalui pembelajaran di kelas, tetapi sekolah dapat juga menerapkannya melalui pembiasaan Kegiatan pembiasaan dapat dilakukan misalnya mengucap salam, bersalaman, mengucapkan salam ketika masuk dan keluar ruangan, membaca basmalah dan hamdalah sebelum dan selesai pembelajaran, membuang sampah pada tempatnya. Kegiatan keteladanan yang dilakukan misalnya, guru mencontohkan datang terlebih dahulu kesekolah sebelum anak-anak samapai ke sekolah, membuang sampah pada tempatnya, bersalaman saat datang dan pulang sekolah.

\section{METODE PENELITIAN}

Penelitian ini termasuk jenis penelitian deskriptif dengan metode penelitian kualitatif. Penelitian ini dilakukan di PAUD Al-Amien Gunung Eleh Kedungdung Sampang pada hari Sabtu 26 Oktober 2019. Dalam penelitian ini melalui teknik pengumpulan informasi yang berupa observasi dan waancara. Observasi dimaksudkan untuk mendapatkan hasil tentang pembelajaran yang diterapkan di PAUD Al-Amien melalui metode keteladana dan pembiasaan untuk membangun karakter AUD. Adapun wawancara dimaksudkan untuk pengumpulan informasi dengan melakukan tanya jawab secara langsung dengan narasumber agar mendapatkan informasi yang tidak terakomodasi dari lembar pedoman observasi.

\section{HASIL DAN PEMBAHASAN}

Guru mempunyai peran penting dalam mendidik dan mengembangkan karakter seorang anak didik. Sebagai pendidik, ia hendaklah dapat menjadi contoh dalam segala aspek kehidupannya (Sitompul, 2016). Karena itu keteladanan guru merupakan suatu metode dalam mendidik dan membentuk sikap anak didik ke arah kebaikan dan bermoral. Seluruh tingkah laku guru baik dalam berbicara, berbuat, bertingkah laku merupakan contoh bagi anak didiknya di dalam mengembangkan sikap dan kepribadiannya.

Keteladanan dalam pendidikan adalah metode yang paling meyakinkan keberhasilannya dalam mempersiapkan dan membentuk sikap anak, moral, spiritual dan sosial yang baik. Hal ini penting dilakukan, karena guru sebagai pendidik adalah contoh terbaik dalam pandangan anak yang akan ditiru melalui tingkah lakunya, sopan santunnya baik disadari atau tidak, bahkan hal itu secara langsung tercetak dalam jiwa dan perasaannya, baik dalam ucapan maupun perbuatan. Keteladanan dari guru adalah sesuatu yang dibutuhkan anak dalam mengembangkan kepribadiannya. Pentingnya keteladanan guru didasarkan kepada adanya kecenderungan anak untuk meniru dan mencontoh perbuatan dan 
tingkah laku orang dewasa. Selain peniruan menanamkan nilai-nilai dan pembentukan sikap harus dilatihkan berulang-ulang atau pembiasaan (Sitompul, 2016).

Pembiasaan adalah salah satu alat pendidikan yang penting sekali terutama bagi anak-anak yang masih kecil, sebab anak-anak belum menyadari tentang baik dan buruk dalam agama dan nilai susila. Perhatian anak selalu selalu berubah dari satu objek kepada objek lain sesuai pengalaman hidup dan bergaul yang mereka alami. Di saat dia memperhatikan hal yang baru kemudian dia melupakan pula hal yang lain, karena itu pembiasaan harus dilakukan pada anak, sehingga terbentuk kebiasaan yang baik pada dirinya. Hal itu bisa dilakukan dengan membiasakannya membantu orang lain, membiasakan mengucapkan basmalah, hamdalah, serta belajar dan bekerja dalam hidupnya secara disiplin (Sitompul 2016).

Berdasarkan hal di atas, berarti penggunaan latihan berulang-ulang atau pembiasaan dan peniruan atau keteladanan diyakini sebagai metode yang patut dan berpengaruh terhadap pembentukan sikap dan penanaman nilai-nilai ajaran agama pada anak. Karena itu di samping keteladanan yang diberikan orangtua dan guru agar ditiru dan dicontoh anak, maka orangtua dan guru juga harus membiasakan dan melatih anak dalam perbuatan-perbuatan yang terpuji baik berupa akhlak maupun pengamalan agama.

Salah satu lembaga yang menerapkan metode keteladanan dan pembiasaan dalam mengembangkan karakter anak usia dini yaitu PAUD Al-Amien. Peneliti akan menguraikan tentang hasil penelitian yang telah dilakukan di PAUD Al-Amien Gunung Eleh Kedungdung Sampang. Penelitian ini dilaksanakan dengan kerja sama antara peneliti dan guru PAUD AlAmien yaitu Ibu Lutfiyah yang sekaligus sebagai kepala sekolah di PAUD tersebut untuk mengetahui pengemplementasian keteladanan guru dalam pembentukan karakter anak didiknya melalui pembiasaan-pembiasaan, sikap dan tingkah laku yang ditunujkkan oleh guru.

Ibu Lutfiah mengatakan bahwa pembinaan keteladanan dan pembiasaan yang dilakukan di PAUD Al-Amien mulai dari awal peserta didik datang ke kelas sampai kembali ke rumah masing-masing. Peserta didik PAUD Al-Amien setiap hari dibiasakan untuk tepat waktu, mereka harus sudah di kelas pukul 07.30 WIB. Kemudian peserta didik dibiasakan untuk mengucapkan salam kepada gurunya. Kegiatan ini dilakukan untuk melatih anak selalu memberi dan membalas salam, sebagai sikap ramah dan mengajarkan peserta didik untuk menghormati gurunya. Begitu pun guru PAUD Al-Amien dibiasakan untuk tepat waktu dalam berbagai hal, hal ini dimaksudkan agar para peserta didik mencontoh gurugurunya. Karena bagaimana pun tauladan bagi seorang guru itu sangatlah penting. Peserta didik di PAUD Al-Amien dibiasakan sebelum KBM untuk mengikuti beberapa pembiasaan di antaranya pembiasaan membaca doa, membaca asmaul husna, dan membaca surat-surat pendek. Setelah mengikuti kegiatan tersebut barulah mereka mengikuti KBM hingga berakhir pada pukul 10:00 WIB. Mereka juga dididik untuk disiplin, sopan, berbuat baik, kerja sama dan saling tolong menolong sesama teman.

Dengan demikian berdasarkan observasi dan wawancara yang telah dilakukan dapat diperoleh hasil penelitian sebagai berikut:

1. Hasil observasi guru

\begin{tabular}{|c|c|c|c|}
\hline No & \multicolumn{1}{|c|}{ Indikator } & \multicolumn{1}{|c|}{ Butir Amatan } & $\begin{array}{c}\text { Hasil } \\
\text { Pengamatan }\end{array}$ \\
\hline 1 & $\begin{array}{l}\text { Memiliki } \\
\text { pengetahuan } \\
\text { keagamaan yang } \\
\text { luas }\end{array}$ & $\begin{array}{l}\text { - Mengucapkan salam dengan ramah } \\
\text { kepada siswa ketika memasuki rung } \\
\text { kelas untuk mencontohkan sikap } \\
\text { santun pada peserta didik }\end{array}$ & Tercapai \\
\hline
\end{tabular}




\begin{tabular}{|c|l|l|l|}
\hline $\begin{array}{l}\text { mengamalkannya } \\
\text { dalam kehidupan } \\
\text { se hari-hari secara } \\
\text { aktif }\end{array}$ & $\begin{array}{c}\text { Berdoa sebelum membuka pelajaran } \\
\text { untuk menanamkan nilai religius }\end{array}$ & \\
\hline 2 & $\begin{array}{l}\text { Meningkatkan } \\
\text { kualitas keilmuan } \\
\text { secara } \\
\text { berkelanjutan }\end{array}$ & $\begin{array}{l}\text { - Melibatkan peserta didik secara aktif } \\
\text { dalam setiap kegiatan pembelajaran } \\
\text { sehingga mereka mempunya sikap } \\
\text { percaya diri dan mandiri } \\
\text { Menstimulasi anak agar mampu } \\
\text { memecahkan masalahnya sendiri }\end{array}$ & Tercapai \\
\hline 3 & Berlaku adil \\
pada peserta didik & $\begin{array}{l}\text { Memberikan stimulasi dan kasih } \\
\text { sayang pada semua anak } \\
\text { Memberikan kesempatan anak untuk } \\
\text { saling berinteraksi dengan teman }\end{array}$ & Tercapai \\
\hline 4 & $\begin{array}{l}\text { Pemaaf, } \\
\text { penyabar } \\
\text { jujur }\end{array}$ & $\begin{array}{l}\text { Bersikap toleran pada karakteristik } \\
\text { dan kemampuan anak yang berbeda- } \\
\text { beda } \\
\text { Bersikap ceria, sopan dan santun agar } \\
\text { anak senantiasa meniru prilaku guru }\end{array}$ & Tercapai \\
\hline
\end{tabular}

2. Hasil observasi anak

\begin{tabular}{|c|c|c|c|}
\hline No & \multicolumn{1}{|c|}{ Indikator } & \multicolumn{1}{c|}{ Butir Amatan } & $\begin{array}{c}\text { Hasil } \\
\text { Pengamatan }\end{array}$ \\
\hline 1 & $\begin{array}{l}\text { Mengenal prilaku baik } \\
\text { sebagai cermin akhlak } \\
\text { mulia }\end{array}$ & $\begin{array}{l}\text { - Anak mampu mengucap salam } \\
\text { saat masuk kelas dan mencium } \\
\text { tangan guru }\end{array}$ & Tercapai \\
\hline 2 & $\begin{array}{l}\text { Memiliki prilaku yang } \\
\text { mencerminkan rendah } \\
\text { hati dan santun kepada } \\
\text { orang tua,pendidik dan } \\
\text { teman. }\end{array}$ & $\begin{array}{l}\text { Anak mampu berprilaku sopan } \\
\text { dengan orang disekitarnya } \\
\text { Anak mampu bermain dengan } \\
\text { baik bersama teman-temannya }\end{array}$ & Tercapai \\
\hline 3 & $\begin{array}{l}\text { Memiliki prilaku yang } \\
\text { mencerminkan sikap } \\
\text { taat terhadap aturan } \\
\text { sehari-hari } \\
\text { melatih kedisiplinan }\end{array}$ & $\begin{array}{l}\text { Anak mampu mengkondisikan } \\
\text { diri saat pembelajaran akan } \\
\text { dimulai } \\
\text { - Anak ikut berdoa dan membaca } \\
\text { surat pendek }\end{array}$ & Tercapai \\
\hline 4 & $\begin{array}{l}\text { Memiliki prilaku yang } \\
\text { mencerminkan } \\
\text { tanggung jawab }\end{array}$ & $\begin{array}{l}\text { Mengembalikan } \\
\text { ketempat semula } \\
\text { Menjawab evaluasi guru dengan } \\
\text { sopan }\end{array}$ & Tercapai \\
\hline 5 & $\begin{array}{l}\text { Memiliki prilaku yang } \\
\text { mencerminkan sikap } \\
\text { peduli dan mau } \\
\text { membentu jika di minta } \\
\text { bantuannya }\end{array}$ & $\begin{array}{l}\text { Mampu bekerjasama dan mau } \\
\text { menolong teman }\end{array}$ & Tercapai \\
\hline
\end{tabular}




\section{KESIMPULAN}

Berdasarkan penelitian yang dilakukan dapat di simpulkan bahwa pengembangan keteladanan dan pembiasaan dalam membentuk karakter anak yang dilakukan oleh guru PAUD Al-Amien berlangsung dengan baik. Dari data yang di peroleh bentuk-bentuk keteladanan dan pembiasaan yang di kembangkan oleh guru dimulai dari sebelum pembelajaran, saat pembelajaran dan sesudah pembelajaran dengan tujuan agar anak terbiasa dengan keteladanan dan pembiasaan yang di terapkan oleh guru. Pengembangan keteladanan dan pembiasaan guru dikatakan berhasil apabila anak mampu meniru, menerapkan, dan melaksanakan apa yang di contohkan oleh gurunya dari hasil penelitiann ini bahwa anak PAUD Al-Amien bahwa anak sudsh msmpu mencontoh dan menerapkan apa yan sudah di contohkan oleh guru mereka. Anka mampu melaksankan keteladanan dan pembiasaan guru dengan baik tampa perlu dikomando terus-menerus oleh guru.

\section{DAFTAR PUSTAKA}

Nisa Titin Faridatun, Membangun Karakter Anak Usia Dini Melalui Pembelajaran Math Character, "Jurnal Pedagogia", Volume. 5, No. 2, Agustus 2016.

Saleh Muwafik, Membangun Karakter Dengan Hati Nurani. Jakarta: Erlangga, 2012.

Shalihah Anisa Khabibahtus, "Nilai-Nilai Pendidikan Karakter", Skripsi Program Sarjana Universitas Islam Negeri Sunan Kalijaga, Yogyakarta, 2013.

Syarifuddin, Peran Strategi Lembaga Pendidikan Tenaga Kependidikan Dalam Membangun Karakter Guru Professional,.Raudhah, Vol. IV, No.1, Januari-juni 2016.

Sitompul Hafsah, Metode Keteladanan Dan Pembiasaan Dalam Penanaman Nilai-Nilai Dan Pembentukan Sikap Pada Anak, "Jurnal Darul 'Ilmi” Vol. 04, No. 01 Januari.

Wawancara dengan Ibu Lutfiyah Selaku Guru dan Kepala Sekolah PAUD Al-Amien pada hari Sabtu, 26 Oktober 2019, Pukul 09: 15 WIB. 